\title{
Modulation of basal glucose metabolism and insulin sensitivity by growth hormone and free fatty acids during short-term fasting
}

\author{
Helene Nørrelund $^{1}$, Steen Nielsen ${ }^{1}$, Jens Sandahl Christiansen ${ }^{1}$, Jens Otto Lunde Jørgensen ${ }^{1}$ and Niels Møller $^{1,2}$ \\ ${ }^{1}$ Medical Department M (Endocrinology and Diabetes) and ${ }^{2}$ Institute of Experimental Clinical Research, Aarhus University Hospital, DK-8000 \\ Aarhus C, Denmark \\ (Correspondence should be addressed to H Norrelund; Email: helenenorrelund@dadlnet.dk)
}

\begin{abstract}
Background and aims: The metabolic response to fasting involves an increase in circulating levels of growth hormone $(\mathrm{GH})$ and free fatty acids, and resistance to insulin's actions on glucose metabolism. Stimulation of lipolysis and insulin resistance are well-described effects of GH. The present study was designed to test the degree to which the insulin antagonistic effects of GH on glucose metabolism are mediated through stimulation of lipolysis during fasting.

Methods: Seven normal subjects were examined on three occasions during a 40-h fast with infusion of somatostatin, insulin and glucagon for the final $18 \mathrm{~h}$ : (expt. i) with GH replacement, (expt. ii) with GH replacement and antilipolysis with acipimox, and (expt. iii) without GH and with antilipolysis.

Results: Basal glucose turnover was significantly reduced by addition of acipimox (rate of disappearance (Rd) glucose $(\mathrm{mg} / \mathrm{kg} / \mathrm{min}$ ): $1.91 \pm 0.08$ (expt. i), $1.69 \pm 0.05$ (expt. ii), $1.61 \pm 0.08$ (expt. iii); $P<0.01$ ), whereas insulin-stimulated glucose uptake was significantly increased (glucose infusion rate (M-value) $(\mathrm{mg} / \mathrm{kg} / \mathrm{min}): 1.66 \pm 0.22$ (expt. i), $2.47 \pm 0.10$ (expt. ii), $2.00 \pm 0.31$ (expt. iii); $P<0.05)$. Addition of $\mathrm{GH}$ during inhibition of lipolysis failed to affect basal and insulin-stimulated glucose metabolism significantly.

Conclusion: Thus, the present data provide strong evidence that the insulin antagonistic effects of GH on fasting glucose metabolism are causally linked to concomitant stimulation of lipolysis.
\end{abstract}

European Journal of Endocrinology 150 779-787

\section{Introduction}

It is well described that prolonged fasting induces insulin resistance (1), which may be related to high circulating levels of growth hormone $(\mathrm{GH})$ and free fatty acids (FFA) (2). Several studies have shown that GH antagonises the effects of insulin on lipid and glucose metabolism, although the underlying mechanism remains uncertain. After an overnight fast physiological elevations in plasma $\mathrm{GH}$ concentrations in humans have been shown to induce insulin resistance in the liver as well as in skeletal muscle $(3,4)$. In fasted dogs, administration of GH was associated with an increase in plasma insulin levels, unchanged glucose turnover, but resistance to the effects of administered insulin (5). In GH-deficient adults continued GH replacement during fasting decreased the glucose infusion rate (M-value) during a glucose clamp, reflecting decreased sensitivity of glucose metabolism to insulin and increased palmitate turnover, reflecting increased lipid mobilization and utilization (6).

Because GH promotes lipolysis in adipose tissue and elevation of $\mathrm{GH}$ is associated with increased plasma
FFA levels (7-13), increased lipid availability has been suggested to be responsible for the insulin resistance observed with elevated GH levels. After GH infusion both GH and FFA levels are positively correlated with the increase in peripheral and hepatic insulin resistance (14), whereas overnight lowering of FFAs with acipimox (an antilipolytic agent) has been shown to improve insulin sensitivity (15). Moreover, postabsorptive insulin resistance induced by GH administration in GH-deficient adults was grossly diminished by concomitant suppression of FFAs (16). Put together, these data may suggest that insulin resistance during fasting is causally linked to $\mathrm{GH}$-induced stimulation of lipolysis. This assumption has not, however, been experimentally tested.

The present study was designed to define the roles of FFAs and GH in the regulation of glucose metabolism during fasting and, more specifically, to test whether the insulin antagonistic effects of GH on glucose metabolism are mediated through stimulation of lipolysis and whether inhibition of lipolysis leads to increased insulin sensitivity. For this purpose we examined seven healthy subjects on three occasions with and without GH and 
pharmacological antilipolysis during $40 \mathrm{~h}$ of fasting together with infusion of somatostatin to clamp hormone levels.

\section{Subjects and methods \\ Experimental protocol (Fig. 1)}

Seven healthy male subjects (mean age $23 \pm 1$ years; body mass index $24 \pm 1 \mathrm{~kg} / \mathrm{m}^{2}$ ) were examined on three occasions during a 40 -h fast with infusion of somatostatin, insulin and glucagon for the final $18 \mathrm{~h}$ to control hormone levels: (expt. i) with GH replacement (+ GH, - acipimox), (expt. ii) with GH replacement and inhibition of lipolysis ( $+\mathrm{GH},+$ acipimox), and (expt. iii) without $\mathrm{GH}$ and with inhibition of lipolysis $(-\mathrm{GH}$, + acipimox) (Fig. 1). Somatostatin $(200 \mu \mathrm{g} / \mathrm{h})$ was infused together with insulin (Actrapid, $100 \mathrm{IE} / \mathrm{ml}$, Novo Nordisk, Copenhagen, Denmark; infusion rate adjusted to maintain plasma glucose levels between 3 and $5 \mathrm{mmol} / \mathrm{l}(0.1 \mathrm{mU} / \mathrm{kg} / \mathrm{min}$ to $0.05 \mathrm{mU} / \mathrm{kg} / \mathrm{min}))$ and glucagon (GlucaGen, $1 \mathrm{ng} / \mathrm{ml}$, Novo Nordisk; the infusion rate being adjusted to maintain stable glucose levels (1.0 to $1.5 \mathrm{ng} / \mathrm{kg} / \mathrm{min})$ ). The somatostatin experiments were identical in terms of hormone replacement doses, except for GH (Norditropin, 12 IU/ml, Novo Nordisk; 4.5 IU partly as bolus injections, partly as continuous infusion) and acipimox (Olbetam; $250 \mathrm{mg}$ p.o. every 4th h). To avoid hypoglycemia during fasting with $\mathrm{GH}$ suppression and antilipolysis, all participants temporarily received glucose intravenously $(0.2 \mathrm{mg} / \mathrm{kg} / \mathrm{min}$ for a period of 0.5 to $1.5 \mathrm{~h}$ ); exactly the same amount of glucose was given in exactly the same manner in the experiment with GH replacement. Since potential hypoglycemia was anticipated during GH suppression, the - GH, + acipimox experiment was conducted first in all subjects, in order to allow for control of exogenous glucose. The subjects were blinded to this procedure. The remaining two experiments were performed in random order with at least 6 weeks elapsing between each experiment. At each investigation a 3-h 'basal' period was followed by a euglycemic 3-h glucose clamp. No participants received glucose during the basal period, as glucose infusion was tapered at least $2 \mathrm{~h}$ before investigations of substrate metabolism were started. Prior to the study, subjects were on a weight maintaining diet for at least 3 months. All subjects gave their written informed consent, and the study was approved by the regional ethics committee and conducted according to the Declaration of Helsinki.

\section{Assays}

The plasma glucose level was measured in duplicate immediately after sampling on a glucose analyzer (Beckman Instruments, Palo Alto, CA, USA). Whole blood glycerol, lactate and $\beta$-hydroxybutyrate $(\mathrm{BOH})$ were analyzed by autofluorimetric enzymatic methods (17). Levels of serum FFAs were determined by a commercial kit (Wako Chemicals, Neuss, Germany). A double monoclonal immunofluometric assay (Delfia, Wallac, Finland) was used to measure serum GH, while plasma glucagon and insulin-like growth factor-I (IGF-I) levels were measured by in-house assays (18-20). Insulin was determined by a commercial immunological kit (DAKO, Glostrup, Denmark) (Immunoclear, Stillwater, MN, USA). Catecholamines were measured by liquid chromatography (21). Cortisol was measured by an automated chemiluminescence system (Chiron Diagnostics, Fernwald, Germany).

\footnotetext{
i. $40 \mathrm{~h}$ fast with suppression of $\mathrm{GH}$ and exogenous $\mathrm{GH}$ replacement (+GH, -acipimox)

ii. $40 \mathrm{~h}$ fast with suppression of $\mathrm{GH}$, exogenous $\mathrm{GH}$ replacement, and inhibition of lipolysis (+GH, +acipimox)

iii. $40 \mathrm{~h}$ fast with suppression of GH and inhibition of lipolysis (-GH, +acipimox)
}

\begin{tabular}{|c|c|c|c|c|c|c|}
\hline Blood sampling, & $\downarrow$ & $\downarrow$ & $\downarrow$ & $\downarrow$ & $\begin{array}{l}\text { Basal } \\
\downarrow \downarrow \downarrow\end{array}$ & Clamp \\
\hline $22 \overline{\mathrm{pm}} / /$ & $20 \mathrm{pm}$ & & & $8 \mathrm{am}$ & & $2 \mathrm{pm}$ \\
\hline 0 & 22 & 26 & 30 & 34 & 37 & 40 \\
\hline
\end{tabular}

Tracer infusion

Insulin clamp + Vamin infusion

Calorimetry

Urine collections

Acipimox (ii+iii)

$\mathrm{X}$

$\mathrm{x}$

$\mathrm{X}$

$\mathrm{x}$

Figure 1 The experimental design (see text for details). 


\section{Euglycemic hyperinsulinemic glucose clamp and indirect calorimetry}

All studies were performed with the participants in the supine position. At $0800 \mathrm{~h}$ a bolus of $20 \mu \mathrm{Ci}\left[3-{ }^{3} \mathrm{H}\right] \mathrm{glu}-$ cose (New England, Nuclear, Boston, MA, USA) was given, followed by a continuous infusion of $20 \mu \mathrm{Ci} / \mathrm{h}$. Three hours were allowed for the isotope to equilibrate. From 1100 to $1400 \mathrm{~h}$ a constant amount $(0.6 \mathrm{mU} / \mathrm{kg} /-$ min) of insulin (Actrapid, Novo Nordisk) was infused; based on measurements every $10 \mathrm{~min}$ plasma glucose was clamped at $5.0 \mathrm{mmol} / \mathrm{l}$ by infusion of variable rates of a $20 \%$ glucose solution. To minimize rapid dilution of the labeled glucose pool with unlabeled glucose, $\left[3-{ }^{3} \mathrm{H}\right]$ glucose was added to the glucose infused during the clamp $(100 \mu \mathrm{Ci} / 500 \mathrm{ml} 20 \%$ glucose $)$. During the clamp, hepatic glucose production (EGP) was calculated by subtracting the amount of exogenous glucose necessary to maintain euglycemia (M-value) from the isotopically determined overall appearance rate for glucose. To prevent hypoaminoacidemia during insulin stimulation, we infused a commercially available amino acid solution Vamin $14 \mathrm{~g}$ nitrogen/l, $0.0176 \mathrm{ml} / \mathrm{kg} / \mathrm{min}$. One liter contained the following amino acids: $12 \mathrm{~g}$ L-alanine, $8.4 \mathrm{~g}$ L-arginine, $2.5 \mathrm{~g}$ asparatate, $420 \mathrm{mg}$ L-cysteine, $4.2 \mathrm{~g}$ L-glutamate, $5.9 \mathrm{~g}$ glycine, $5.1 \mathrm{~g}$ L-histidine, $4.2 \mathrm{~g}$ L-isoleucine, $5.9 \mathrm{~g}$ L-leucine, $6.8 \mathrm{~g}$ L-lysine, $4.2 \mathrm{~g}$ L-methionine, $5.9 \mathrm{~g}$ L-phenylalanine, $5.1 \mathrm{~g}$ L-proline, $3.4 \mathrm{~g}$ L-serine, $4.2 \mathrm{~g}$ L-threonine, $1.4 \mathrm{~g}$ L-tryptophane, $170 \mathrm{mg}$ L-tyrosine, $5.5 \mathrm{~g}$ L-valine in sterile water. Indirect calorimetry (Deltatrac monitor, Datex Instrumentarium, Helsinki, Finland) allowed measurements of respiratory exchange ratios (RERs). Net lipid and glucose oxidation rates $(\operatorname{Rd}(\mathrm{ox}))$ were calculated from the above measurements. Net nonoxidative glucose disposal (Rd(non-ox)) was calculated by subtracting oxidative glucose disposal $(\operatorname{Rd}(\mathrm{ox}))$ from total glucose disposal (Rd) measured isotopically.

\section{Microdialysis}

The microdialysis technique allows repeated sampling of interstitial fluid from adipose tissue and was used for measurement of interstitial levels of glucose, lactate and glycerol. A microdialysis catheter (CMA 60, CMA, Stockholm, Sweden) was placed in the abdominal s.c. adipose tissue after anesthetization of the skin with $0.05 \mathrm{ml}$ lidocaine at the site of perforation of the skin. The microdialysis catheter used has a molecular cutoff of $20 \mathrm{kDa}$. Immediately after placement, perfusion of the catheters with physiological perfusion fluid (perfusion fluid T1, CMA; $\mathrm{Na}^{+}, 147 \mathrm{mmol} / \mathrm{l} ; \mathrm{K}^{+}, 4 \mathrm{mmol} / \mathrm{l}$; $\mathrm{Ca}^{2+}, 2.3 \mathrm{mmol} / \mathrm{l} ; \mathrm{Cl}^{-}, 156 \mathrm{mmol} / \mathrm{l}, \mathrm{pH}, 6$; osmolality, $290 \mathrm{mosmol} / \mathrm{kg}$ ), at a flow rate of $0.3 \mathrm{ml} / \mathrm{min}$, with the use of a portable pump (CMA 106, CMA), was accomplished. At this flow rate, the rate of recovery with the microdialysis catheter is almost $100 \%$ (22).
The microdialysis catheter was placed at $t=0$ min. After $1 \mathrm{~h}$ of calibration with perfusion of the microdialysis catheter, allowing local edema and hemorrhage to subside, sampling started at $t=60 \mathrm{~min}$ and continued, every $60 \mathrm{~min}$, until $t=360 \mathrm{~min}$. The first sample was thus withdrawn at $t=120 \mathrm{~min}$. It reflects the integrated level of interstitial glucose from $t=60 \mathrm{~min}$ to $t=120 \mathrm{~min}$. In the figure the sample is assigned $90 \mathrm{~min}$ (Fig. 2). This principle was used for all samples. The observed changes in interstitial glycerol concentration can be seen as an index of lipolysis (23-25).

\section{Forearm technique}

Muscle substrate balance can be assessed by the forearm method, which quantifies muscle uptake and
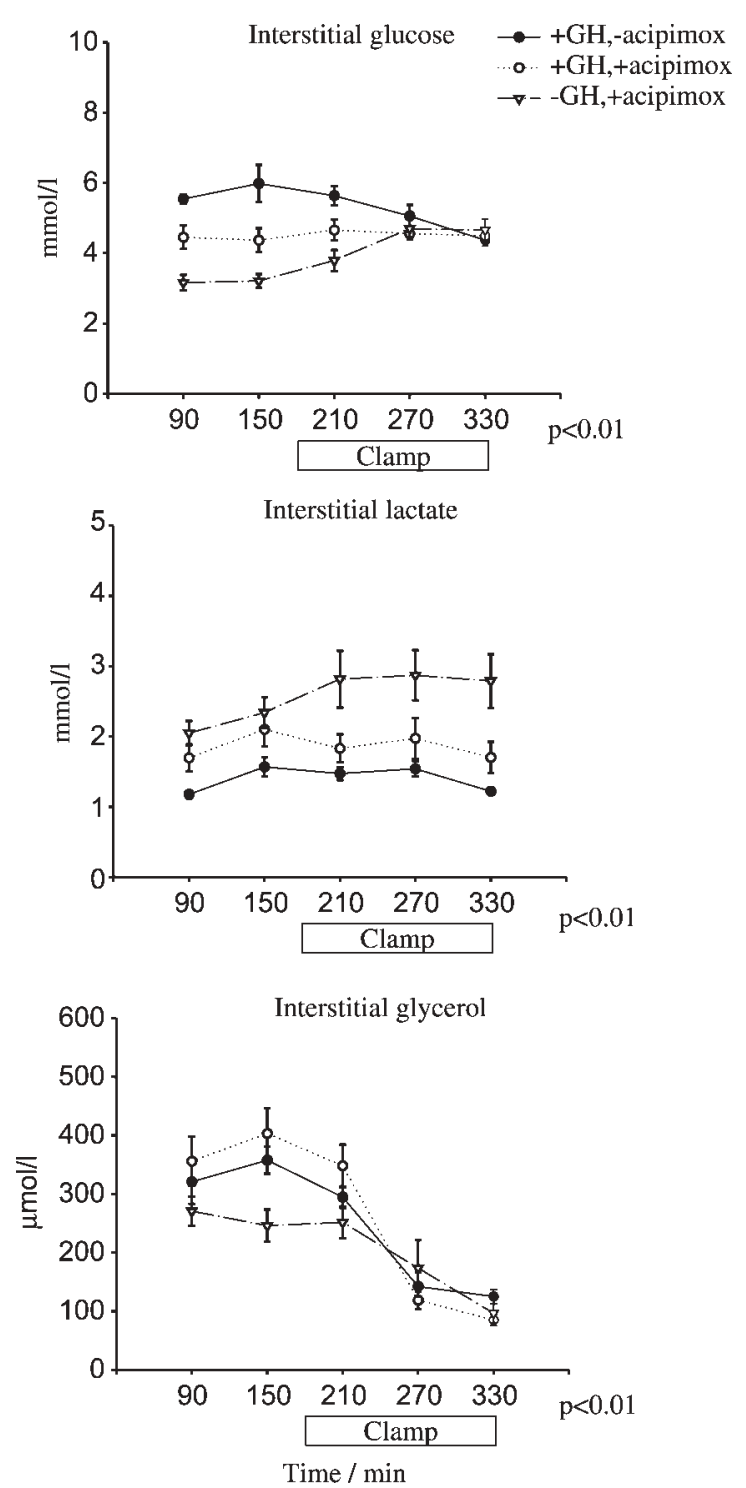

Figure 2 Interstitial metabolite concentrations in the three experiments as determined by microdialysis (means \pm S.E.). 
release of metabolites. Arterialized and deep-venous blood samples were drawn simultaneously from the heated dorsal hand vein and the deep antecubital vein respectively. Before the blood samples were drawn the hand blood flow was interrupted for at least $1 \mathrm{~min}$ by inflation of a wrist cuff to $250 \mathrm{mmHg}$. Immediately after the blood samples were drawn, the forearm blood flow was measured by venous occlusion plethysmography.

\section{Statistics}

Results are expressed as means \pm S.E.M. The Kolmogorov-Smirnov test was used to test for normal distribution. Statistical comparisons between the study periods ( $+\mathrm{GH}$, - acipimox; $+\mathrm{GH}$, + acipimox; $-\mathrm{GH}$, + acipimox) were assessed by a two-way analysis of variance (ANOVA). If this test was positive, post hoc comparison was carried out by means of a paired $t$-test (to test the effect of lipolysis (expt. i vs expt. ii) and the effect of GH (expt. ii vs expt. iii)). For time series (i.e. circulating hormones) the area under the curve (AUC) was calculated by the trapezoidal method and comparisons were made by analysis of variance. A P-value below 0.05 was considered significant. Unless specified otherwise data referred to below were obtained with arterialized blood based on triplicate measurements during the last $30 \mathrm{~min}$ of the basal and clamp periods.

\section{Results}

\section{Circulating hormones and protein metabolites}

Inhibition of lipolysis led to an $80 \%$ increase in GH concentration despite somatostatin infusion (Table 1). Total IGF-I (tIGF-I) and free IGF-I (fIGF-I) decreased and the counterregulatory hormone, epinephrine, increased. The addition of GH during inhibition of lipolysis was associated with an increase in glucagon and a decrease in norepinephrine.

The total plasma concentration of amino acids was not affected by administration of $\mathrm{GH}$ or acipimox (total amino acids $(\mu \mathrm{mol} / \mathrm{l})$ : $2470 \pm 87$ (expt. i), $2552 \pm 53$ (expt. ii), $2378 \pm 181$ (expt. iii); $P>0.05$ ). Overall, the gluconeogenic amino acids did not differ, although alanine decreased when GH was added during antilipolysis (alanine ( $\mu \mathrm{mol} / \mathrm{l}): 235 \pm 12$ (expt. i), $255 \pm 9$ (expt. ii), $325 \pm 17$ (expt. iii); $P<0.01$ ).

\section{Lipid metabolism}

Acipimox administration lowered circulating concentrations of lipid intermediates (FFA and glycerol) (Table 2) and halved the concentration of BOH. FFA and glycerol tended to escape the action of the drug after $12 \mathrm{~h}$ since an increase in circulating concentrations of FFA, glycerol, and interstitial glycerol (Fig. 2) was seen in the presence of GH.

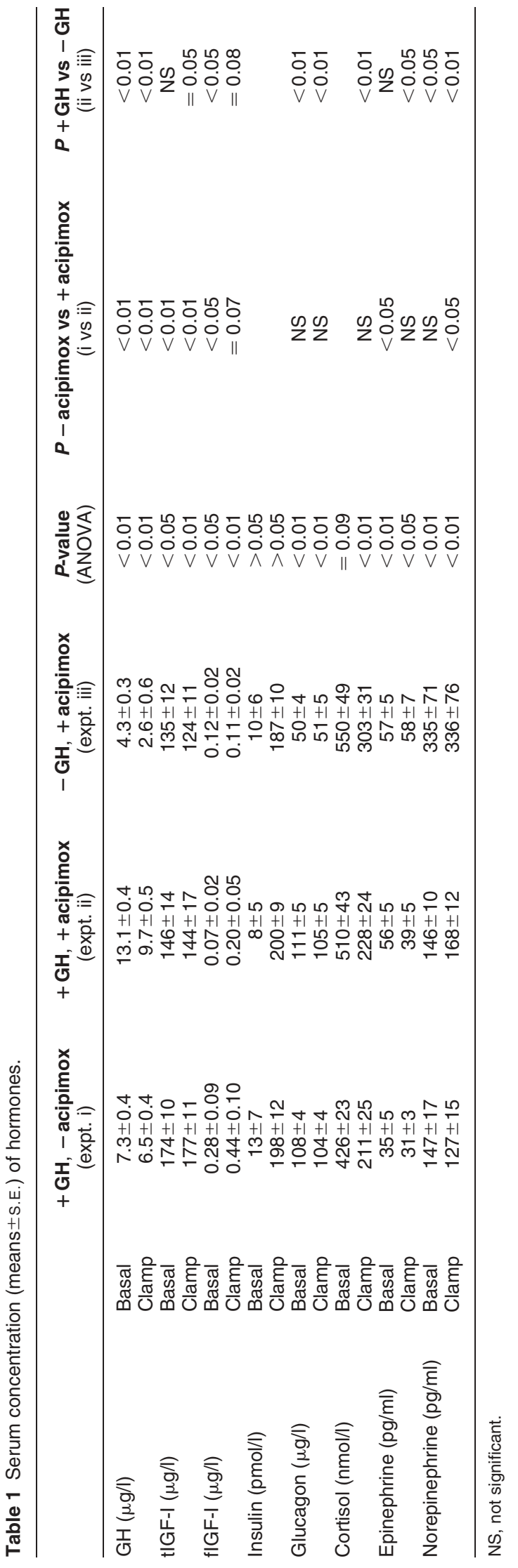


After $34 \mathrm{~h}$ of fasting, lipid oxidation (ox) was reduced by $40-50 \%$ by acipimox (lipid ox $(\mathrm{mg} / \mathrm{kg} / \mathrm{min})$ (basal): $0.97 \pm 0.08$ (expt. i), $0.43 \pm 0.08$ (expt. ii), $0.64 \pm 0.07$ (expt. iii); $P<0.01)$. The respiratory exchange ratio (RER) was increased (RER: 0.80 0.01 (expt. i), $0.87 \pm 0.02 \quad$ (expt. ii), $0.84 \pm 0.01 \quad$ (expt. iii); $P<0.05$ ), whereas energy expenditure (EE) decreased

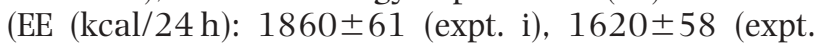
ii), $1594 \pm 118$ (expt. iii); $P<0.05$ ). During the clamp lipid oxidation tended to be decreased during fasting with antilipolysis (lipid ox ( $\mathrm{mg} / \mathrm{kg} / \mathrm{min})$ (clamp): $0.74 \pm 0.08$ (expt. i), $0.48 \pm 0.14$ (expt. ii), $0.40 \pm 0.08$ (expt. iii); $P=0.09$ ).

\section{Glucose metabolism and insulin sensitivity}

Plasma glucose was decreased $20 \%$ by inhibition of lipolysis whereas lactate was increased (Table 2). Addition of $\mathrm{GH}$ during antilipolysis was associated with a significant increase in glucose, whereas lactate decreased. Steady-state interstitial glucose values were approximately 15\% lower than in plasma (Fig. 2) but the three study periods showed proportional concentrations compared with plasma. After $34 \mathrm{~h}$ of fasting a significant increase in glucose oxidation was observed during fasting with suppression of lipolysis $(\operatorname{Rd}(\mathrm{ox})$ (mg/kg/min): $1.16 \pm 0.16$ (expt. i), $1.86 \pm 0.21$ (expt. ii), $1.52 \pm 0.21$ (expt. iii); $P<0.05$ ), whereas the basal rate of endogenous glucose production was significantly reduced by addition of acipimox at the end of the basal period ( $\mathrm{Rd}$ glucose $(\mathrm{mg} / \mathrm{kg} / \mathrm{min})$ : $1.91 \pm 0.08$ (expt. i), $1.69 \pm 0.05$ (expt. ii), $1.61 \pm 0.08$ (expt. iii); $P<0.01$ ) (Table 3). Insulin-stimulated glucose uptake was significantly increased during antilipolysis (M-value (mg/kg/min): $1.66 \pm 0.22$ (expt. i), $2.47 \pm 0.10$ (expt. ii), $2.00 \pm 0.31$ (expt. iii); $P<0.05$ ) (Fig. 3) and glucose utilization (Rd) tended to be increased during fasting with antilipolysis $(P=0.07)$ (Table 3). Addition of GH during antilipolysis did not affect glucose uptake $(P=0.18)$. Hepatic glucose production tended to be decreased during acipimox treatment with GH substitution (EGP $(\mathrm{mg} / \mathrm{kg} / \mathrm{min})$ : $0.83 \pm 0.15$ (expt. i), $0.50 \pm 0.07$ (expt. ii), $0.97 \pm 0.29$ (expt. iii); $P=0.16)$. Since carbohydrate oxidation rates were similar $(P>0.05)$, the difference in glucose disposal is most likely caused by a difference in non-oxidative glucose utilization, although our data failed to reach statistical significance ( $\operatorname{Rd}($ non-ox) $(\mathrm{mg} / \mathrm{kg} / \mathrm{min})$ (clamp): $1.39 \pm 0.28$ (expt. i), $1.70 \pm 0.23$ (expt. ii), $1.44 \pm 0.45$ (expt. iii); $P>0.05)$.

\section{Forearm blood flow and exchange of metabolites}

Forearm blood flow as assessed by plethysmography was not affected by administration of either $\mathrm{GH}$ or acipimox. Consequently, forearm exchange of metabolites are given as arterio-venous differences in plasma 


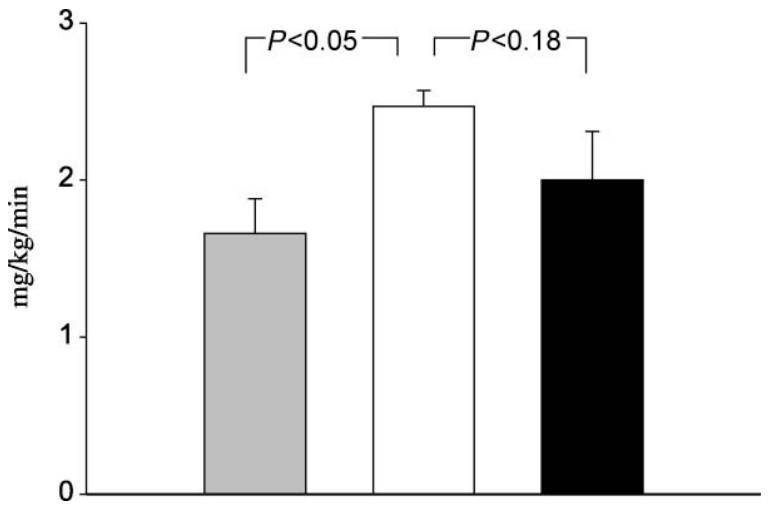

Figure 3 Insulin sensitivity as assessed by M-value (means \pm S.E.) during the hyperinsulinemic clamp. Shaded bar, $+\mathrm{GH}$,

- acipimox; open bar, $+\mathrm{GH}$, + acipimox; solid bar, $-\mathrm{GH}$,

+ acipimox. $P<0.05$. The shaded bar is significantly different from the open bar.

concentrations of metabolites. Insulin-stimulated uptake of FFAs was significantly decreased during antil-

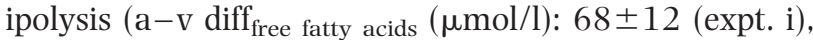
$19 \pm 8$ (expt. ii), $-4 \pm 12$ (expt. iii); $P<0.01$ ), whereas no significant change was found in glucose uptake. Lactate was released during fasting with antilipolysis and $\mathrm{GH}$ replacement $(\mathrm{a}-\mathrm{v}$ diff lactate $(\mu \mathrm{mol} / \mathrm{l}): 4 \pm 29$ (expt. i), $-59 \pm 18$ (expt. ii), $54 \pm 44$ (expt. iii); $P=0.05$ ).

\section{Discussion}

The present study was designed to assess the acute effect of GH and FFAs on glucose metabolism and insulin sensitivity during short-term fasting. The main findings are first that inhibition of lipolysis induces a clearcut decrease in basal glucose turnover and EGP and increases insulin sensitivity, and secondly that administration of $\mathrm{GH}$ during inhibition of lipolysis fails to affect basal and insulin-stimulated glucose metabolism significantly.

Several studies have shown that GH postabsorptively antagonises the effects of insulin on glucose and lipid metabolism $(4,9,26)$. During fasting and stress, GH secretion is augmented and studies in GH-deficient adults have demonstrated that $\mathrm{GH}$ replacement during fasting in $\mathrm{GH}$-deficient subjects increases lipid oxidation and decreases insulin sensitivity $(6,27)$. The mechanisms by which GH induces insulin resistance during fasting remain to be precisely defined. Randle and colleagues in 1963 proposed the existence of a glucose fatty acid (28), and although the underlying mechanisms are still the subject of dispute, the concept of substrate competition has been supported by numerous studies. Suppression of circulating levels of FFA, induced by pharmacological antilipolysis, increased insulin sensitivity $(15,29,30)$, and lipid infusion has been observed to inhibit glucose uptake and carbohydrate oxidation $(31,32)$. Postabsorptively, the insulin resistance induced by $\mathrm{GH}$ administration in 
GH-deficient adults was clearly reduced by concomitant suppression of FFA (16). In as much as insulin sensitivity, judged by the M-value, tended, if anything, to be increased (2.5 vs $2.0 \mathrm{mg} / \mathrm{kg} / \mathrm{min}$ ) during GH administration when lipolysis was blocked, our results clearly suggest that the ability of GH to induce insulin resistance during fasting is entirely secondary to stimulated lipolysis. The specific mechanism by which FFAs influence glucose metabolism in muscle tissue has not been resolved yet. Recent data challenge the original mechanisms proposed to be operative according to the Randle hypothesis, as the FFA-induced decrement in glycogen synthesis has been shown to be preceded by a lowering of intracellular glucose-6-phosphate (33), and FFA have been demonstrated to lower intracellular glucose concentrations (34). Taken together, these observations suggest that FFA lower glucose disposal primarily by inhibition of transmembrane glucose transport (35).

Traditionally, insulin was believed to inhibit endogenous glucose production exclusively through direct actions. However, studies in dogs (36-39) have suggested that at least some of insulin's effects are indirect and may be mediated by lowering of plasma FFA. The role of FFAs in the regulation of glucose production in vivo seems relatively complex, involving both direct effects and indirect effects secondary to alterations in circulating concentrations of glucoregulatory hormones. In normal overnight-fasted human volunteers, experimental increments in FFA levels induced by the combined infusion of triglycerides and heparin are usually not associated with any significant change in glycemia or endogenous glucose production $(40-42)$. The potential increase in hepatic glucose output induced by FFA is antagonized by their stimulatory effect on insulin secretion, and several reports indicate that the suppression of this hormonal effect by somatostatin is necessary to unveil the hyperglycemic action of FFA $(41,43)$. Similarly, the experimental lowering of FFA levels postabsorptively does not inhibit $(29,30,44-48)$ and may even stimulate hepatic glucose output $(49,50)$, possibly through a reduction in insulin secretion and an increase in glucagon levels. In the present study we intended to control FFA, insulin, glucagon, and GH. During the basal period, as would be expected, inhibition of lipolysis was associated with a decrease in glucose production. This is in line with results from Mittelman et al. (51) showing that suppression of lipolysis under constant basal insulin causes suppression of EGP, despite a significant rise in catecholamines.

Despite the fact that glucagon was administered in exactly the same amount in all three situations, the plasma level was significantly decreased during fasting with suppression of GH and inhibition of lipolysis (expt. iii). The low circulating levels during antilipolysis and suppression of $\mathrm{GH}$ are presumably due to an increase in glucagon clearance. The regulation of glucagon clearance remains controversial. The circulating serine protease dipeptidyl peptidase IV seems to be a primary enzyme involved in the degradation and inactivation of glucagon (52); regulation of this peptide, however, remains to be clarified. In the present study the low glucagon levels found during suppression of $\mathrm{GH}$ and antilipolysis (expt. iii) could add to the decrease in glucose production in this situation, but since glucagon levels were comparable during GH replacement (expt. i) and GH replacement and antilipolysis (expt. ii), the decrease in EGP caused by antilipolysis cannot be explained by glucagon. It should, however, be noted that rates of glucose disposal during the clamp also tended to be elevated during GH administration and that glucagon is not thought to have any effects on the disposal of glucose.

The levels of FFAs were suppressed by acipimox, which is known to exert its antilipolytic effect by lowering the intracellular level of cyclic adenosine monophosphate (cAMP) and thereby inhibiting the activity of the hormone-sensitive lipase (53). That the effects of antilipolysis on glucose metabolism may have been due to an intrinsic effect of acipimox, cannot entirely be excluded. When FFA levels are clamped to separate any direct or pharmacological effects of acipimox on glucose uptake from secondary effects of inhibiting lipolysis, glucose oxidation during a euglycemic, hyperinsulinemic clamp $(29,54)$ in healthy subjects and suppression of EGP by insulin in noninsulin-dependent diabetic (NIDDM) subjects (46) are not affected by acipimox. On the other hand, during hyperinsulinemia Fulcher et al. (54) demonstrated a minute increase in glucose disposal due to increased non-oxidative glucose disposal after acipimox administration. In the presence of basal insulin concentrations peripheral glucose uptake is not altered acutely in acipimox-treated NIDDM subjects $(30,55)$. Thus, the bulk of evidence suggests that acipimox does not have any direct effects on glucose metabolism.

In conclusion, our results show that experimental lowering of circulating FFA levels with acipimox during fasting suppresses endogenous glucose production, increases insulin sensitivity and abolishes any anti-insulin effects of GH on glucose metabolism. Thus stimulation of lipolysis must be a pivotal - and perhaps the only - mechanism for the insulin antagonistic actions of $\mathrm{GH}$ on fasting glucose metabolism.

\section{Acknowledgements}

GH preparations were generously supplied by Novo Nordisk (Copenhagen, Denmark). The study was supported by Novo Nordisk Foundation, Aage \& Johanne Louis-Hansen Foundation, the Danish Research Council, grant number 9600822 (Novo Nordisk Center for Research in Growth and Regeneration, Aarhus University). Dr K G M M Alberti (University of 
Newcastle-upon-Tyne, Newcastle-upon-Tyne, UK) and Dr Frederik Andreasen (University of Aarhus, Aarhus, Denmark) kindly provided the measurements of glycerol, 3-OH-butyrate, and catecholamines.

\section{References}

1 Bjorkman O \& Eriksson LS. Influence of a 60-hour fast on insulinmediated splanchnic and peripheral glucose metabolism in humans. Journal of Clinical Investigation 198576 87-92.

2 Nørrelund H, Nair KS, Jørgensen JOL, Christiansen JS \& Møller N. The protein-retaining effects of growth hormone during fasting involve inhibition of muscle-protein breakdown. Diabetes 2001 50 96-104.

3 Bratusch-Marrain PR, Smith D \& De Fronzo RA. The effect of growth hormone on glucose metabolism and insulin secretion in man. Journal of Clinical Endocrinology and Metabolism 1982 55 973-982.

4 Rizza RA, Mandarino LJ \& Gerich JE. Effects of growth hormone on insulin action in man. Mechanism of insulin resistance, impaired suppression of glucose production, and impaired stimulation of glucose utilization. Diabetes $1982 \mathbf{3 1} 663-669$.

5 Rathgeb I, Steele R, Winkler B \& Altszuler N. Influence of fasting on changes in glucose metabolism induced by growth hormone injection in the normal dog. Diabetes 197019 487-491.

6 Nørrelund H, Djurhuus C, Jørgensen JO, Nielsen S, Nair KS, Schmitz O et al. Effects of growth hormone on urea, glucose and lipid metabolism and insulin sensitivity during fasting in GH-deficient patients. American Journal of Physiology (Endocrinology and Metabolism) 2003285 E737-E743.

7 Møller N, Jørgensen JO, Schmitz O, Møller J, Christiansen JS, Alberti KG et al. Effects of a growth hormone pulse on total and forearm substrate fluxes in humans. American Journal of Physiology (Endocrinology and Metabolism) 1990258 E86-E91.

8 Fowelin J, Attvall S, von Schenck H, Smith U \& Lager I. Characterization of the insulin-antagonistic effect of growth hormone in man. Diabetologia $199134500-506$.

9 Bak JF, Møller N \& Schmitz O. Effects of growth hormone on fuel utilization and muscle glycogen synthase activity in normal humans. American Journal of Physiology (Endocrinology and Metabolism) 1991260 E736-E742.

10 Jørgensen JO, Møller J, Alberti KG, Schmitz O, Christiansen JS, Ørskov $\mathrm{H}$ et al. Marked effects of sustained low growth hormone (GH) levels on day-to-day fuel metabolism: studies in GH-deficient patients and healthy untreated subjects. Journal of Clinical Endocrinology and Metabolism 199377 1589-1596.

11 Ho KK, O'Sullivan AJ \& Hoffman DM. Metabolic actions of growth hormone in man. Endocrine Journal 199643 S57-S63.

12 Salomon F, Cuneo RC, Umpleby AM \& Sonksen PH. Glucose and fat metabolism in adults with growth hormone deficiency. Clinical Endocrinology $1994 \mathbf{4 1} 315-322$.

13 Jørgensen JO, Møller N, Lauritzen T, Alberti KG, Ørskov H \& Christiansen JS. Evening versus morning injections of growth hormone $(\mathrm{GH})$ in $\mathrm{GH}$-deficient patients: effects on 24-hour patterns of circulating hormones and metabolites. Journal of Clinical Endocrinology and Metabolism 199070 207-214.

14 Neely RDG, Rooney DP, Bell PM, Bell NP, Sheridan B, Atkinson AB et al. Influence of growth hormone on glucose-glucose-6-phosphate cycle and insulin action in normal humans. American Journal of Physiology 1992263 E980-E987.

15 Santomauro ATMG, Boden G, Silva MER, Rocha DM, Santos RF, Ursich MJM et al. Overnight lowering of free fatty acids with acipimox improves insulin resistance and glucose tolerance in obese diabetic and nondiabetic subjects. Diabetes 199948 1836-1841.

16 Nielsen S, Møller N, Christiansen JS \& Jørgensen JO. Pharmacological antilipolysis restores insulin sensitivity during growth hormone exposure. Diabetes $2001502301-2308$.
17 Harrison J, Hodson AW, Skillen AW, Stappenbeck R, Aigus L \& Alberti KGMM. Blood glucose, lactate, pyruvate, glycerol, 3-hydroxybutyrate and acetoacetate measurements in man using a centrifugal analyser with a fluorimetric attachment. Journal of Clinical Chemistry and Clinical Biochemistry 198826 $141-146$.

18 Ørskov H, Thomson HG \& Yde H. Wick chromatography for rapid and reliable immunoassay of insulin, glucagon and growth hormone. Nature $1968219193-195$.

19 Frystyk J, Dinesen B \& Ørskov H. Non-competitive time-resolved immunofluorometric assays for determination of human insulin-like growth factor I and II. Growth Regulation $1995 \mathbf{5}$ $169-176$.

20 Frystyk J, Skjærbæk C, Dinnesen B \& Ørskov H. Free insulin-like growth factors (IGF-I and IGF-II) in human serum. FEBS Letters $1994348185-191$.

21 Erikkson BM \& Persson AB. Determination of catecholamines in rat heart tissue and plasma samples by liquid chromatography. Journal of Chromatography, Biomedical Applications $1982 \mathbf{2 2 8}$ 143-154.

22 Moberg E, Hagstrom-Toft E, Arner P \& Bolinder J. Protracted glucose fall in subcutaneous adipose tissue and skeletal muscle compared with blood during insulin-induced hypoglycaemia. Diabetologia 199740 1320-1326.

23 Jansson PA, Smith U \& Lonnroth P. Interstitial glycerol concentration measured by microdialysis in two subcutaneous regions in humans. American Journal of Physiology $1990 \mathbf{2 5 8}$ E918-E922.

24 Arner P \& Bolinder J. Microdialysis of adipose tissue. Journal of Internal Medicine $1991230381-386$.

25 Hagstrom-Toft E, Enoksson S, Moberg E, Bolinder J \& Arner P. Absolute concentrations of glycerol and lactate in human skeletal muscle, adipose tissue, and blood. American Journal of Physiology 1997273 E584-E592.

26 Møller N, Butler PC, Antsiferov MA \& Alberti KGMM. Effects of growth hormone on insulin sensitivity and forearm metabolism in normal man. Diabetologia 198932 105-110.

27 Nørrelund H, Møller N, Nair KS, Christiansen JS \& Jørgensen JO. Continuation of growth hormone $(\mathrm{GH})$ substitution during fasting in GH-deficient patients decreases urea excretion and conserves protein. Journal of Clinical Endocrinology and Metabolism 2001 86 3120-3129.

28 Randle PJ, Garland PB, Hales CN \& Newsholme EA. The glucosefatty acid cycle, its role in insulin sensitivity and the metabolic disturbances of diabetes mellitus. Lancet 19631 785-789.

29 Piatti PM, Monti LD, Caumo A, Conti M, Magni F, Galli-Kienle M et al. Mediation of the hepatic effects of growth hormone by its lipolytic activity. Journal of Clinical Endocrinology and Metabolism $1999841658-1663$.

30 Vaag A, Skott P, Damsbo P, Gall MA, Richter EA \& Beck-Nielsen H. Effect of the antilipolytic nicotinic acid analogue acipimox on whole-body and skeletal muscle glucose metabolism in patients with non-insulin dependent diabetes mellitus. Journal of Clinical Investigation $1991 \mathbf{8 8} 1282-1290$.

31 Boden G, Jadali F, White J, Liang Y, Mozzoli M, Chen X et al. Effects of fat on insulin-stimulated carbohydrate metabolism in normal men. Journal of Clinical Investigation 1991 88 960-966.

32 Yki-Jarvinen H, Puhakainen I \& Koivisto VA. Effect of free fatty acids on glucose uptake and nonoxidative glycolysis across human forearm tissues in the basal state and during insulin stimulation. Journal of Clinical Endocrinology and Metabolism $1991721268-1277$.

33 Roden M, Price TB, Perseghin G, Petersen KF, Rothman DL, Cline GW et al. Mechanism of free fatty acid-induced insulin resistance in humans. Journal of Clinical Investigation $1996 \mathbf{9 7}$ 2859-2865.

34 Dresner A, Laurent D, Marcucci M, Griffin ME, Dufour S, Cline GW et al. Effects of free fatty acids on glucose transport and IRS-1-associated phosphatidylinositol 3-kinase activity. Journal of Clinical Investigation 1999103 253-259. 
35 Shulman GI. Cellular mechanisms of insulin resistance. Journal of Clinical Investigation $2000 \mathbf{1 0 6} 171-176$.

36 Ader M \& Bergman RN. Peripheral effects of insulin dominate suppression of fasting hepatic glucose production. American Journal of Physiology 1990258 E1020-E1032.

37 Mittelman SD, Fu YY, Rebrin K, Steil G \& Bergman RN. Indirect effect of insulin to suppress endogenous glucose production is dominant, even with hyperglucagonemia. Journal of Clinical Investigation $19971003121-3130$.

38 Rebrin K, Steil GM, Getty L \& Bergman RN. Free fatty acid as a link in the regulation of hepatic glucose output by peripheral insulin. Diabetes 199544 1038-1045.

39 Rebrin K, Steil GM, Mittelman SD \& Bergman RN. Causal linkage between insulin suppression of lipolysis and suppression of liver glucose output in dogs. Journal of Clinical Investigation $1996 \mathbf{9 8}$ $741-749$.

40 Balasse EO \& Neef MA. Operation of the 'glucose-fatty acid cycle' during experimental elevations of plasma free fatty acid levels in man. European Journal of Clinical Investigation 1974 4 247-252.

41 Boden G \& Jadali F. Effects of lipid on basal carbohydrate metabolism in normal men. Diabetes $199140686-692$.

42 Clore JN, Glickman PS, Nestler JE \& Blackard WG. In vivo evidence for hepatic autoregulation during FFA-stimulated gluconeogenesis in normal humans. American Journal of Physiology 1991 261 E425-E429.

43 Ferrannini E, Barrett EJ, Bevilacqua S \& De Fronzo RA. Effect of fatty acids on glucose production and utilization in man. Journal of Clinical Investigation $1983 \mathbf{7 2} 1737-1747$.

44 Jahoor F, Klein S \& Wolfe R. Mechanism of regulation of glucose production by lipolysis in humans. American Journal of Physiology 1992262 E353-E358.

45 Lee KU, Park JY, Kim CH, Hong SK, Suh KI, Park KS et al. Effect of decreasing plasma free fatty acids by acipimox on hepatic glucose metabolism in normal rats. Metabolism 199645 1408-1414.

46 Saloranta C, Franssila-Kallunki A, Ekstrand A, Taskinen MR \& Groop L. Modulation of hepatic glucose production by non-esterified fatty acids in type 2 (non-insulin-dependent) diabetes mellitus. Diabetologia 199134 409-415.
47 Walker M, Agius L, Orskov H \& Alberti KGMM. Peripheral and hepatic insulin sensitivity in non-insulin-dependent diabetes mellitus: effect of nonesterified fatty acids. Metabolism $1993 \mathbf{4 2}$ 601-608.

48 Farrer M, Fulcher GR, Johnson AJ, Record CO \& Alberti KGMM. Effect of acute inhibition of lipolysis on operation of the glucose-fatty acid cycle in hepatic cirrhosis. Metabolism 199241 465-470.

49 Fery F, Plat L, Baleriaux M \& Balasse EO. Inhibition of lipolysis stimulates whole body glucose production and disposal in normal postabsorptive subjects. Journal of Clinical Endocrinology and Metabolism 199782 825-830.

50 Balasse EO \& Neef MA. Influence of nicotinic acid on the rates of turnover and oxidation of plasma glucose in man. Metabolism 197322 1193-1204.

51 Mittelman SD \& Bergman RN. Inhibition of lipolysis causes suppression of endogenous glucose production independent of changes in insulin. American Journal of Physiology (Endocrinology and Metabolism) 2000279 E630-E637.

52 Pospisilik JA, Hinke SA, Pederson RA, Hoffman T, Rosche F, Schlenzig D et al. Metabolism of glucagon by dipeptidyl peptidase IV (CD26). Regulatory Peptides 200196 133-141.

53 Christie AW, McCormick DK, Emmison N, Kraemer FB, Alberti KG \& Yeaman SJ. Mechanism of anti-lipolytic action of acipimox in isolated rat adipocytes. Diabetologia 199639 45-53.

54 Fulcher GR, Walker M, Farrer M, Johnson AS \& Alberti KGMM. Acipimox increases glucose disposal in normal man independent of changes in plasma nonesterified fatty acid concentration and whole-body lipid oxidation rate. Metabolism $199342308-314$.

55 Fulcher GR, Walker M, Catalano C, Farrer M \& Alberti KGMM. Acute metabolic and hormonal responses to the inhibition of lipolysis in non-obese patients with non-insulin-dependent (type 2) diabetes mellitus: effects of acipimox. Clinical Science $1992 \mathbf{8 2}$ 565-571.

Received 31 October 2003

Accepted 1 March 2004 